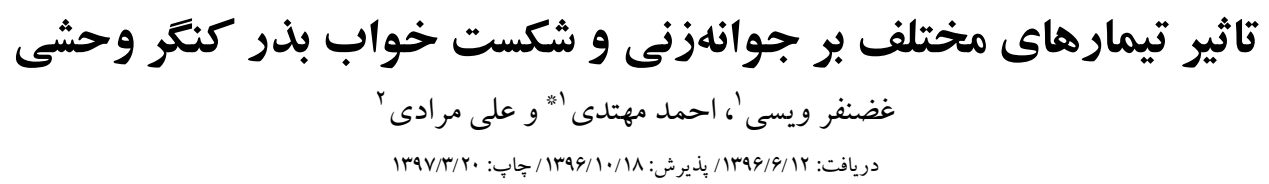

$$
\begin{aligned}
& \text { اخروه زيستشناسى، دانشكده علوم بايه، دانشخاه ياسوج، ياسوج، ايران }
\end{aligned}
$$

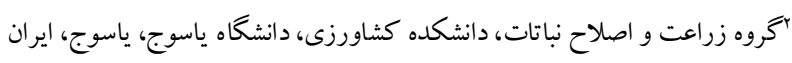

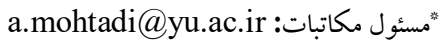

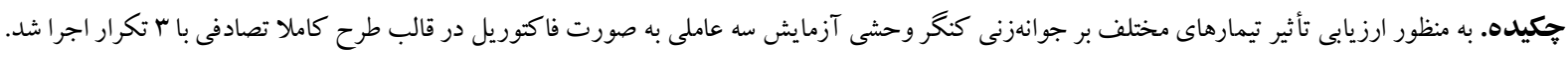

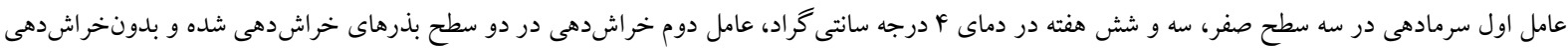

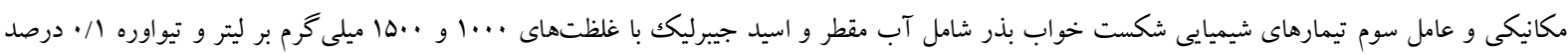

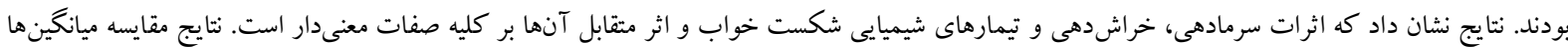

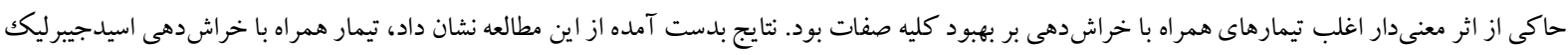

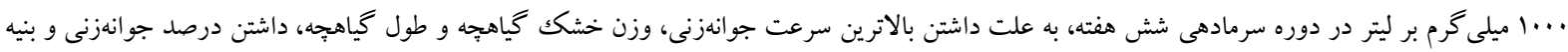

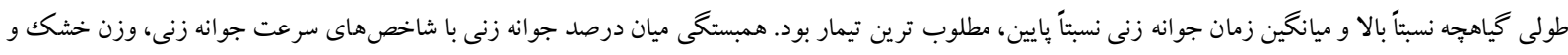

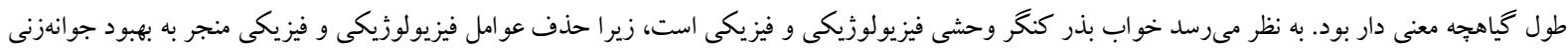

$$
\begin{aligned}
& \text { آن شد. } \\
& \text { وازههاى كليدى. اسيدجيبريك،، تيواوره، خراشدهى، خواب فيزيولوزيكى، سرمادهى }
\end{aligned}
$$

\title{
The effect of different treatments on seed germination and dormancy breaking in seeds of Gundelia tournefortii
}

\author{
Ghazanfar Vaisi ${ }^{1}$, Ahmad Mohtadi $^{*}$ \& Ali Moradi ${ }^{2}$ \\ Received 04.09.2017/ Accepted 08.01.2018/ Published 10.06.2018
}

${ }^{1}$ Department of Biology, Faculty of Science, Yasouj University, Yasouj, Iran

${ }^{2}$ Department of Agronomy and Plant Breeding, Faculty of Agriculture, Yasouj University, Yasouj, Iran

*Correspondent author: a.mohtadi@yu.ac.ir

\begin{abstract}
In order to investigate different treatment effects on germination in Gundelia tournefortii, three factorial experiments were carried out in a completely randomized design with three replications. The first factor was stratification at $4^{\circ} \mathrm{C}$ at three levels including 0,3 and 6 weeks, the second factor was mechanical scarification at two levels including seeds with/without scarification and the third factor was chemical treatments of seed dormancy breaking at three levels including distilled water and gibberellic acid at concentrations of 1000 and $1500 \mathrm{mg} / 1 \mathrm{and}$ Thiourea $0.1 \%$. The results showed that the effects of stratification, scarification and chemical treatments of dormancy breaking and their interactions were significant on all studied parameters $(\mathrm{p}<0.01)$. Mean comparison values were significant for the effects of spate treatments together with mechanical scarification for the improvement of all traits. The results also revealed that the treatment of mechanical scarification treatment together with gibberellic acid 1000 $\mathrm{mg} / \mathrm{l}$ in six weeks stratification, due to maximum germination speed, seedling dry weight, seedling length, large-scale germination percentage and seedling vigor index and modest average germination period, was the most influential treatment for seed dormancy breaking of this plant. Correlation between germination percentage with germination rate, dry weight and seedling length was significant. It seems that seed dormancy type in Gundelia tournefortii is physiological and physical, as eliminating physiological and physical factors leads to its germination improvement.
\end{abstract}

Keywords. gibberellic acid, physiological dormancy, scarification, stratification, thiourea 
كاهى سازو كار شكستن خواب بذر وارد كردن صدمهُ فيزيكى و

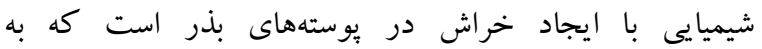
اسكاريفيكاسيون معروف است و در مواردى به كار مىرود كه

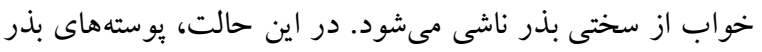

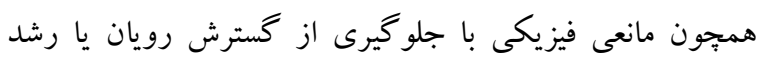
ريشهجه، يا ازطريق ايجاد محدوديت در جذب آب و تبادلات

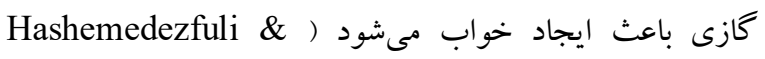
.Aghaalikhani, 1998 در يزووهش Nabaee و همكاران (2013) دربارهٔ شكستن خواب بذر گياه خارمريم (Silybum marianum (L.) Gaertn) از تيره كاسنيان با استفاده از تيمارهاى اسيد جيبرليك، كينتين، اكسين و براسينواستروئيد، گزارش شد كه بهترين تيمار در بين اين تيمارها

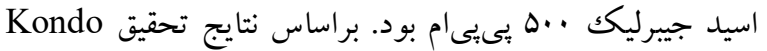
(1993)، از بين تيمارهاى مختلف شيميايى و فيزيكى در يونجهُ زرد (نotus corniculatus L. var. japonicus Regel تنها برش با اسكالٍل و سوراخكردن يوستهُ بذر با سوزن تشريح

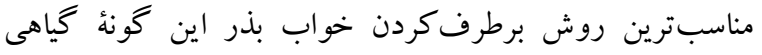
است. Por-Esmaeel و Sharifi (2003) با بررسى تأثير تيمار سرما و برخى سيتو كينينها بر شكستن خواب بذر زيرهٔ سياه (Bunium persicum (Boiss.) B.Fedtsch.)

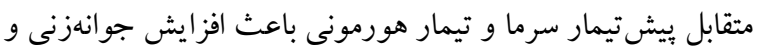

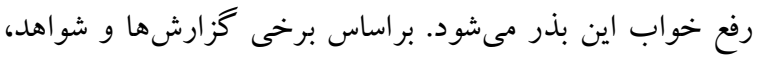
تيو اوره مىتو اند جايخزين تسريع كنندهاى رشد شود ( Ahmad .et al., 2003 شكست خواب بذر آنتابخردان گزارش كردند كه تيمار ا گرم محلول تيواوره ها دقيقه و خيساندن بذر در آب بهمدت يكك شب،

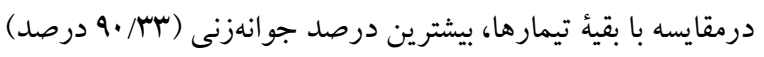
را نتيجه مىدهد. هدف اين بثروه بررسى اثر تيمارهاى مختلف بر شكست خواب و افزايش جوانهزنى گياه كنكر وحشى است.

\section{مواد و روشها}

يُزوهش حاضر در سال هوها در آزمايشگاه فيزيولوزى كياهى

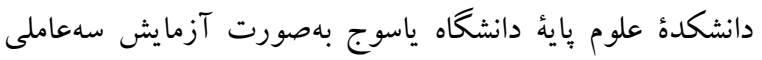

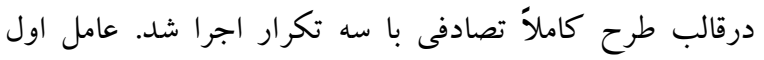
سرمادهى در سه سطح، عامل دوم خراشدهى در دو سطح و عامل
مقدمه

كنگ وحشى با نام علمى .Gundelia tournefortii L. مقلى

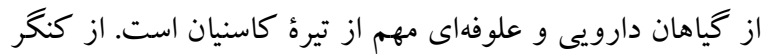

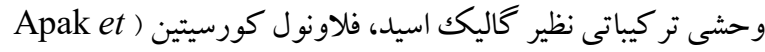
(al., 2007 ، كومارينهاى اسكويوليتين، ايزو اسكويوليتين،

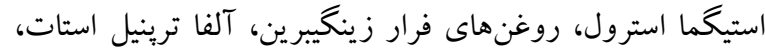

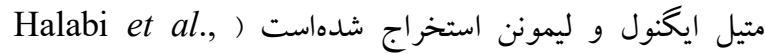
2005). اضافه كردن كنگر به محيط كشت برخى از باكترىهايى إنى

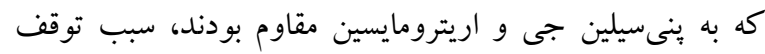
رشد باكترىها شده است. در طب سنى تركيه از دانهاى خشكى

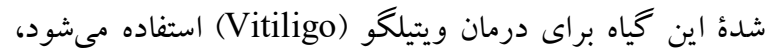

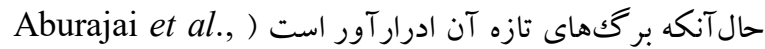

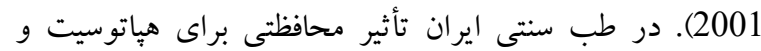
درمان بيمارىهاى كبدى گزارش شده است ( Jamshidzadeh et al., 2005

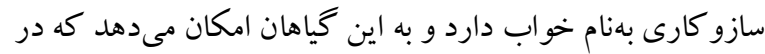
مقابل اوضاع نامساعد محيطى زنده بمانند (Tajbakhsh, 1996).

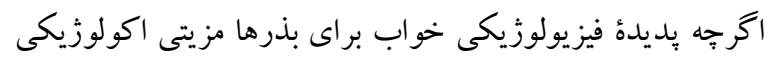

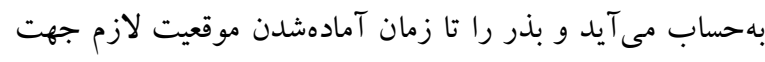

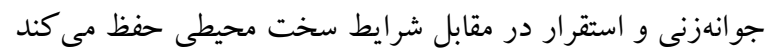
(Nasiri et al., 2004)، اين بديدة فيزيولوزيكى از مشكلات

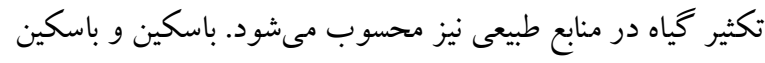

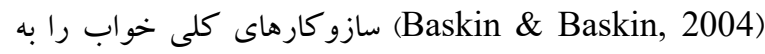
ينج گروه تقسيمبندى كردند: فيزيكى، فيزيولوزيكى، مورفولو -

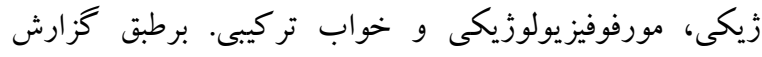

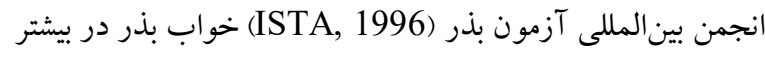

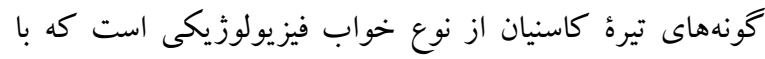

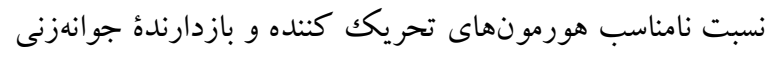

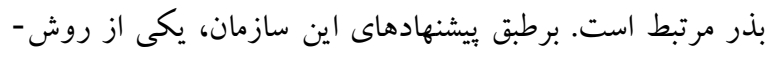

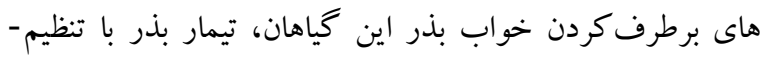

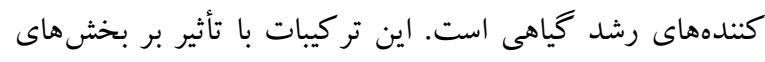

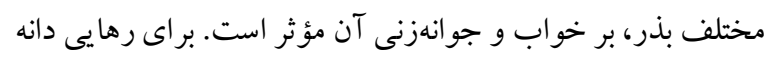

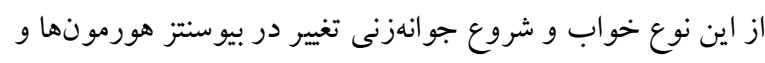
كاهش نسبت ABA/GA لازم است كه همراه با كاهش حساسيت

$$
\text { به ABA و افزايش حساسيت به GA رخ مىدهد. }
$$


طول گياهجه، وزن خشك گياهجه و شاخص بنية گياهجه ارزيابى

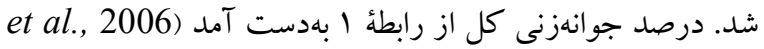
\% Gp $=\frac{n}{N} \times 1$. Fang Gp كل بذرهاى كشتشده است.

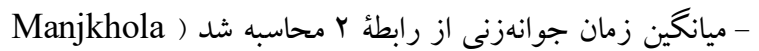
MGT $=\frac{\sum \mathrm{D} \times \mathrm{n}}{\mathrm{N}} \quad$ : (رابطة $\mathrm{Y}$ (et al., 2003

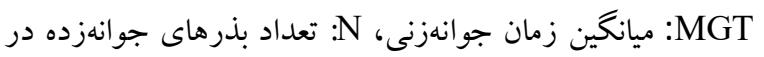

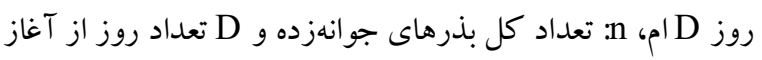
جوانهزنى است.

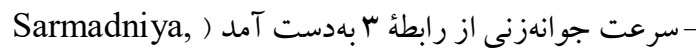

$$
R=\sum \frac{N}{D}
$$

1996). (رابطة $)^{\text {1 }}$ R سرعت جو انهزنى، N: تعداد بذرهاى جوانهزده در هر روز و D : تعداد روزهاى سبرى شده است).

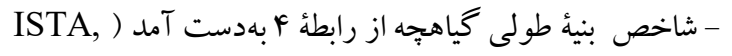

$$
\text { VI }=\frac{\mathrm{Ls} \times \mathrm{Gp}}{100} \quad \text { 2010): (ر) }
$$
:VI

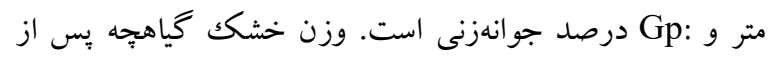

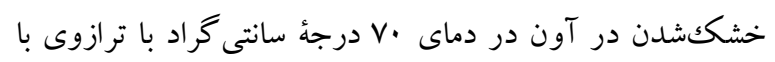

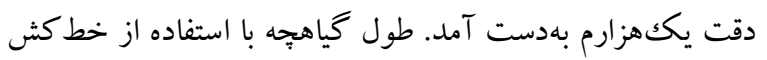
برحسب ميلىمتر اندازه گيرى شد. براى اندازه كيرى فعاليت آنزيم

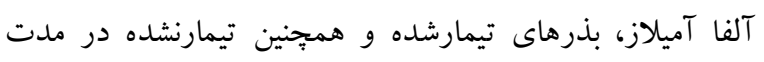

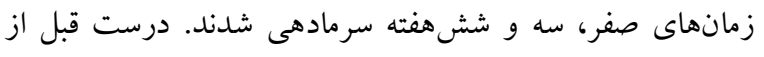

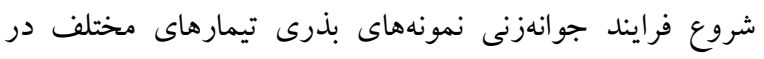

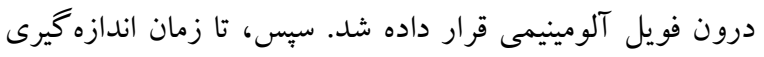

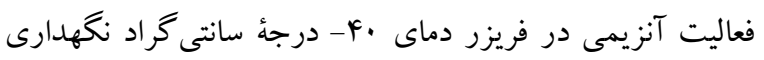

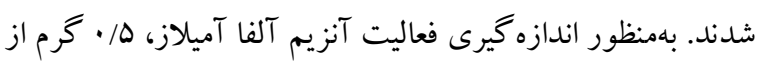

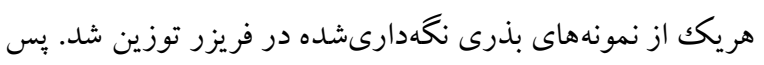

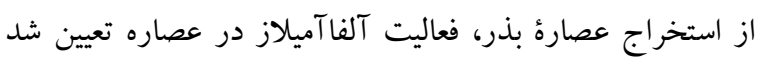

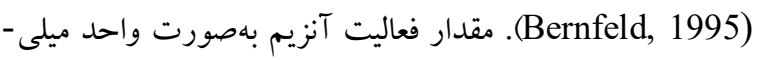

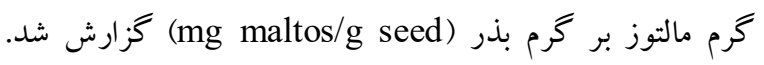

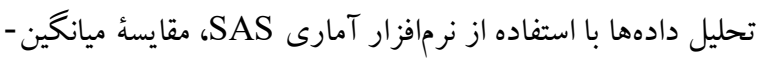

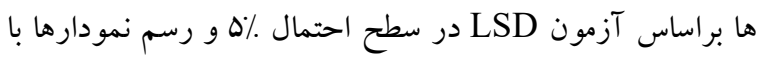

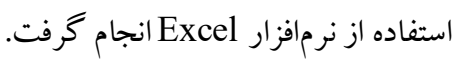

سوم تيمارهاى شيميايى در سه سطح بود. تيمارهاى اعمالشده عبارت بودند از: شاهد (تيمارنشده)، اسيد جيبرليك با غلظتهاى تهاى

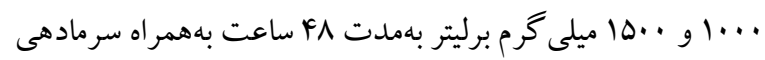
بهمدت صفر، سه و ششهفته در دماى جهار درجهُ سانتى گراد،

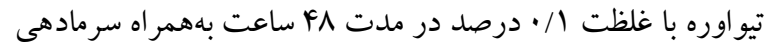
به مدت صفر، سه و ششهفته در دماى جهار درجهُ سانتى گراد،

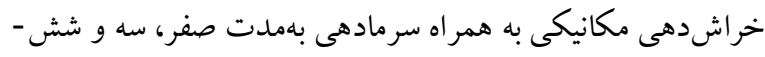

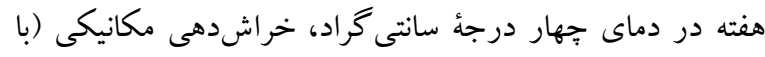

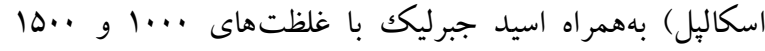

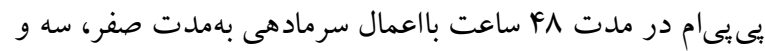

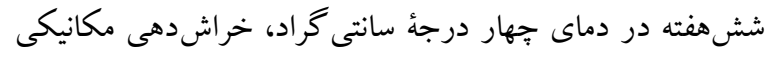

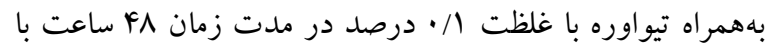
اعمال سرمادهى بهمدت صفر، سه و ششهفته در دماى جهار

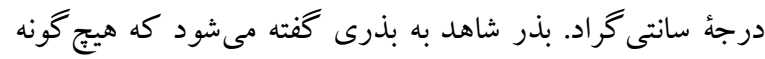
تيمارى بلغير از آب مقطر روى آن اعمال نشده است. بذور كياه

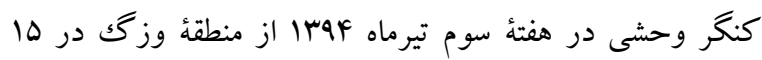

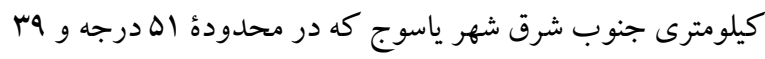

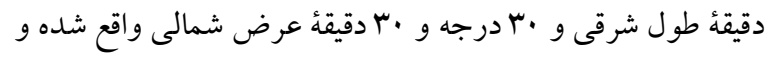

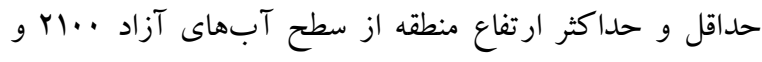

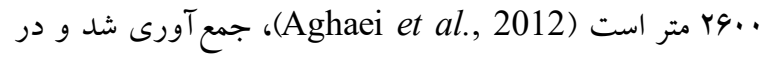
محيط مناسب و بدون رطوبت در يخجال نخهدارى شد. جهت ارزيابى ميزان زندهبودن جنين آنها، از آزمون تترازوليوم طبق بحري

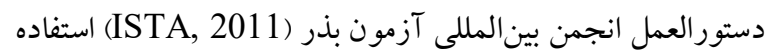

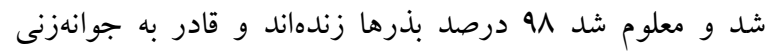
هستند. جهت بهحداقلرساندن خطا و افزايش دقت تا حد امكان بذرها سالم و يكسان انتخاب و جداسازى شدند. قبل از اعمال

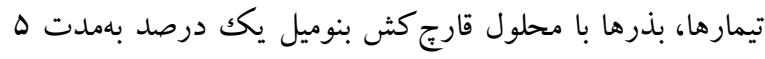

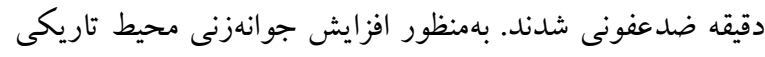

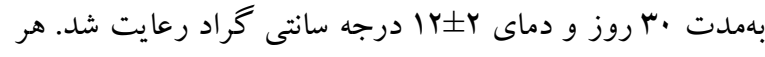

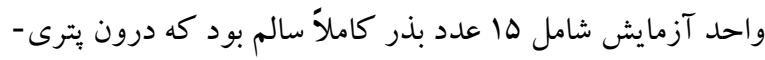

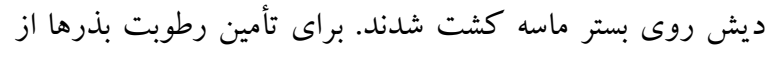

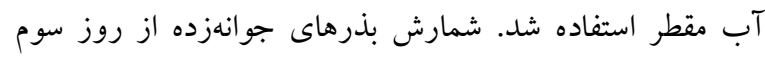
دوره جوانهزنى آغاز شد. يس از اتمام آزمون جو انهزنى صفات

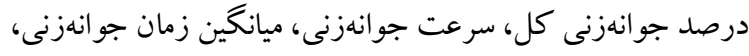


جدول 1- تحليل واريانس (ميانكين مربعات) تيمارهاى شكست خواب بذر بر برخى شاخصههاى جوانهزنى كنكر وحشى.

Table 1. Analysis of variance (mean squares) of seed dormancy breaking treatments on some germination traits of $G$. tournefortii.

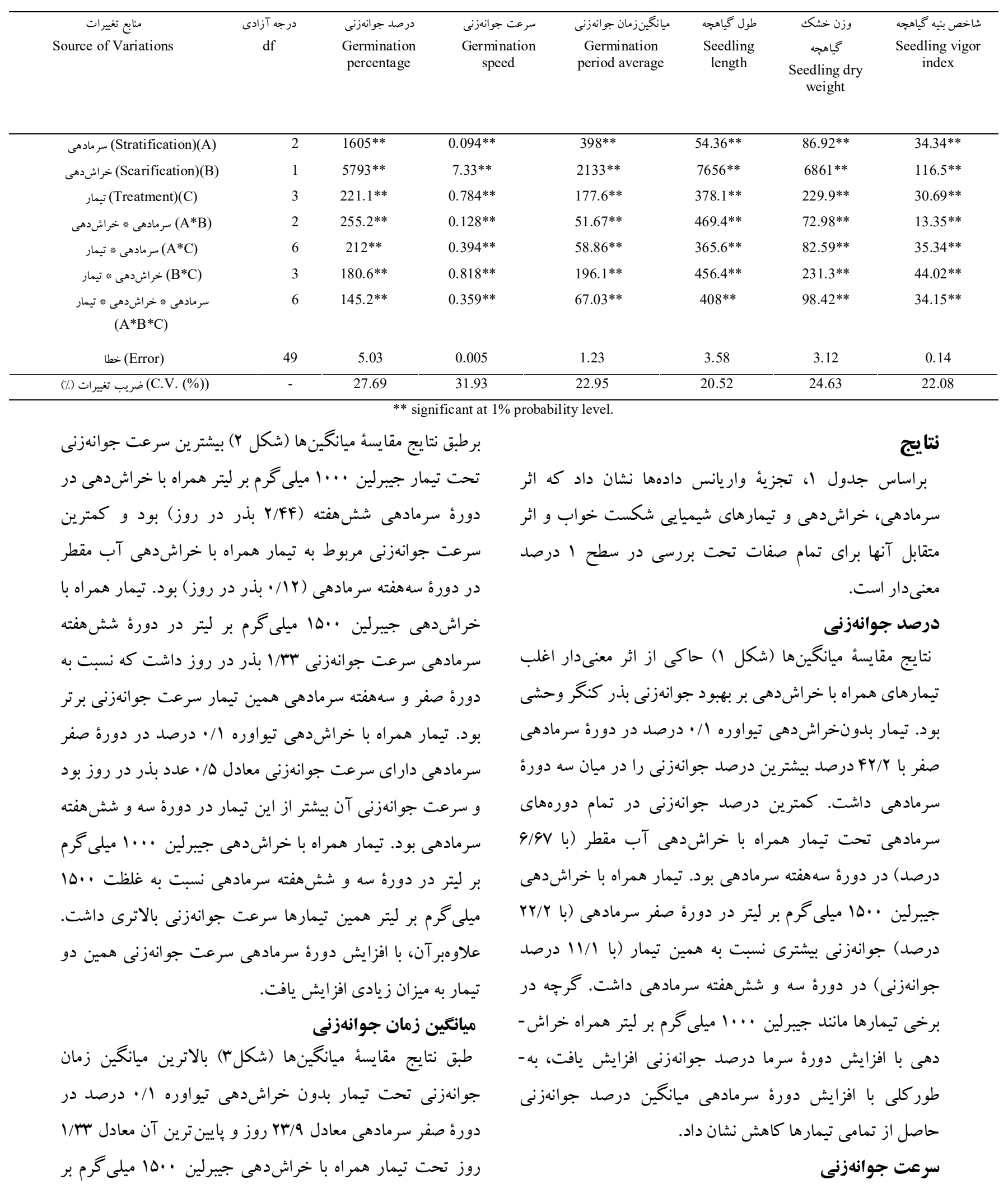




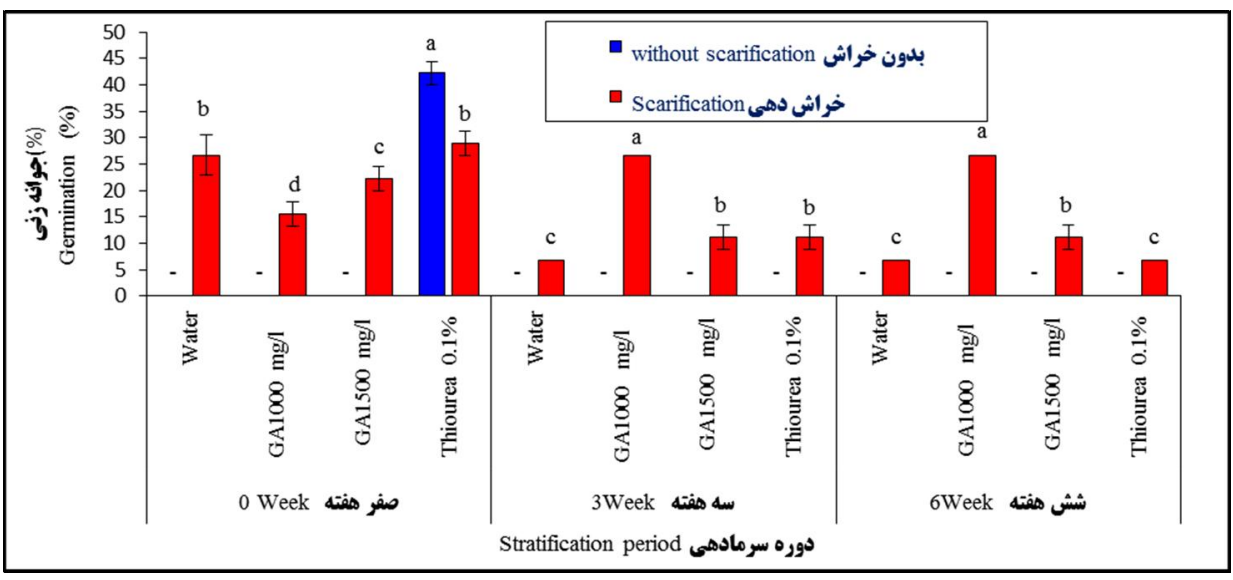

شكل 1 - مقايسه ميانكين برهم كنش بين سرمادهى، خراشدهى و تيمارهاى شيميايى شكست خواب براى صفت درصد جو انهزنى در بذر كنگر وحشى (ستونهاى با

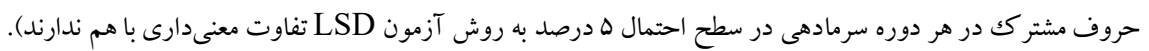

Fig. 1. Mean comparisons of interaction among stratification, scarification and dormancy breaking chemical treatments for germination percentage of G.tournefortii. (Columns having a common letter in each stratification period are not significantly different from each other according to LSD 0.05).

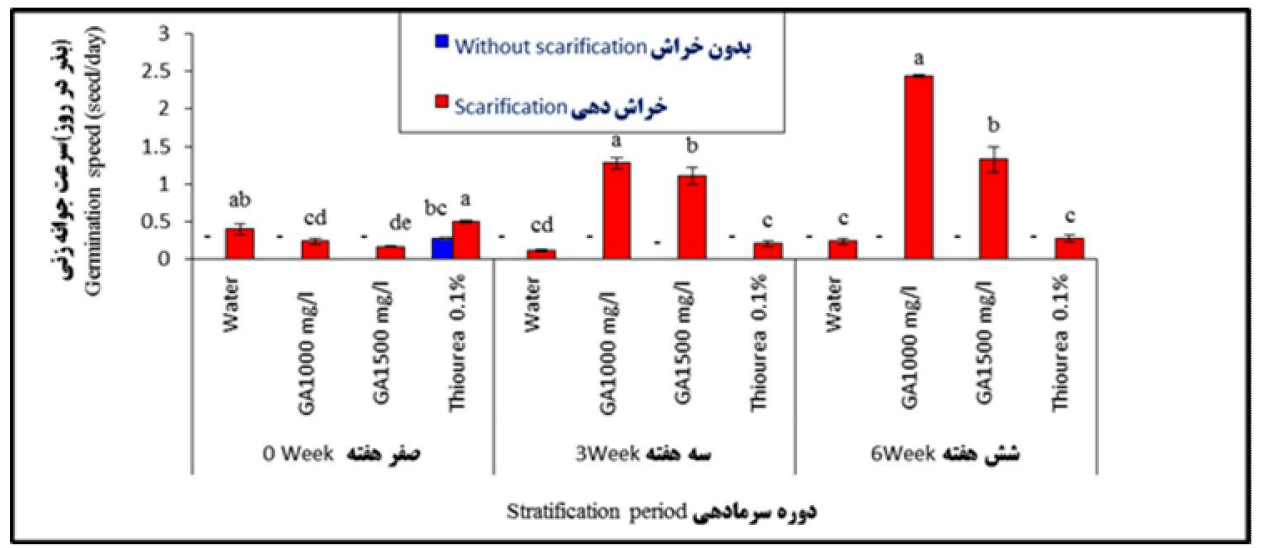

شكل r - مقايسه ميانگين برهم كنش بين سرمادهى، خراشدهى و تيمارهاى شيميايى شكست خواب براى صفت سرعت جوانهزنى در بذر كنكر وحشى (ستو نهاى با

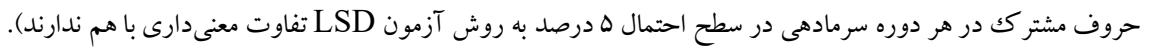

Fig. 2. Mean comparisons of interaction among stratification, scarification and dormancy breaking chemical treatments for germination speed of G.tournefortii. (Columns having a common letter in each stratification period are not significantly different from each other according to LSD 0.05).

\section{طول Fياهֶُه}

براساس جدول rا، نتايج مقايسٔ ميانخينها حاكى از اثر معنى دار

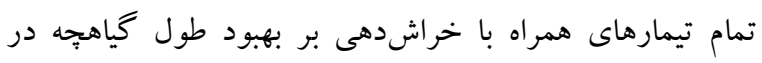
كنگ ششهفته سرمادهى بيشتر از بقيئ دورهها بود و بالاترين طول گياهجه تحت تيمار همراه با خراشدهى جيبرلين ...1 ميلى گرم بر ليتر در اين دورهُ سرمادهى (معادل سM/MN ميلىمتر) بود كه ازنظر آمارى با تيمار همراه با خراشدهى جيبرلين · لمها ميلى گرم
ليتر در دورهُ ششهفته سرمادهى بود. تيمار همراه با خراشدهى جيبرلين . لما ميلى گرم بر ليتر در دورة صفر سرمادهى ميانخين

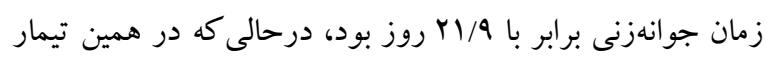

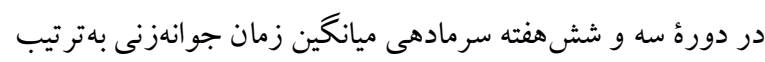

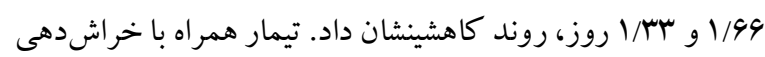
جيبرلين .... ميلى گرم بر ليتر در دورهُ صفر سرمادهى ميانخين زمان جوانهزنى ه/ه روز بود، درحالى كه اين ميانگين در دورة سه به و شش هفته سرمادهى به ترتيب 19/ ا او 19/ب روز بود. 


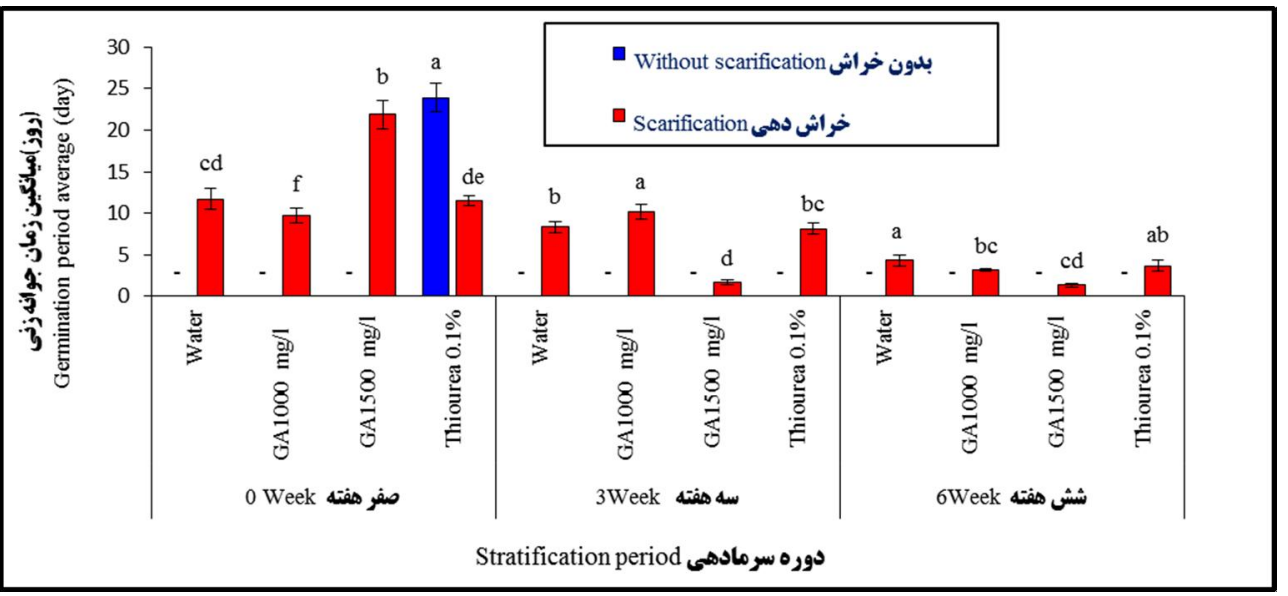

شكل " - مقايسه ميانگين برهم كنش بين سرمادهى، خراشدهى و تيمارهاى شيميايى شكست خواب براى صفت ميانگين زمان جو انهزنى در بذر كنكر وحشى (ستون-

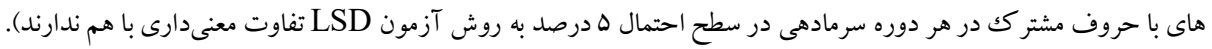

Fig. 3. Mean comparisons of interaction among stratification, scarification and dormancy breaking chemical treatments for average germination period of G.tournefortii. (Columns having a common letter in each stratification period are not significantly different from each other according to LSD 0.05).

غلظت ... ‥ ميلى گرم بر ليتر جيبرلين همراه با خراشدهى (به -

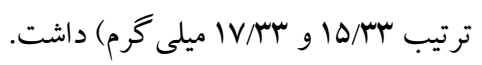

شاخص بنية طولى كياهجه

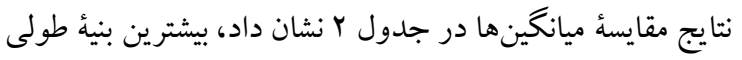

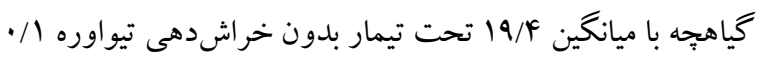
درصد در دورهُ صفر سرمادهى حاصل شد، درحالى كه كمترين بنية طولى مربوط به تيمار همراه با خراشدهى آب مقطر (Fq/•) در دورة سههفته سرمادهى بود. در تيمار همراه با خراشدهى

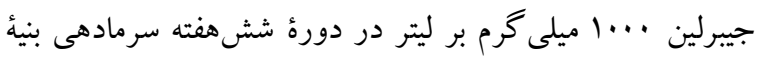
طولى كياهجه I I ب/M بود كه نسبت به همين تيمار در دورة صفر

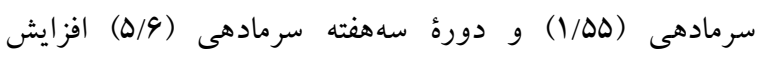
جشمخيرى داشت. همخينين، در تيمار همر اه با خراشدهى جيبرلين 10. . ميلى گرم بر ليتر با افزايش دوره سرمادهى بنية طولى بذر روند صعودى نشان داد، اما در تيمار همراه خراشدهى تيواوره / • درصد اين شاخص بهترتيب افزايش دورهٔ سرما تا ششهفته

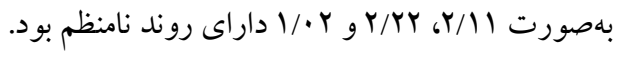
فعاليت آنزيم آلفآميلاز

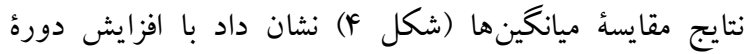
سرمادهى، ميانگين فعاليت آنزيم آلفآميلاز در تمام تيمارها روند افزايشى نشان داد، بهطورى كه بيشترين ميزان فعاليت اين آنزيم،
بر ليتر در همين دوره و تيمار بدون خراشدهى تيواوره // د درصد در دورهُ صفر سرمادهى بدون تفاوت معنىدار بود. بايينترين طول

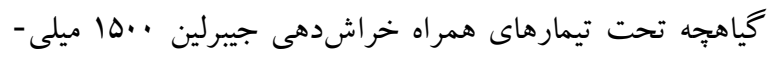
كرم بر ليتر در دورهٔ سرمادهى صفر (معادل سم/V ميلىمتر) بود. در هر دو غلظت همراه با خراشدهى جيبرلين با افزايش دورهُ سرما تا شش هفته ميانگين طول گياهجهها روند افزايشى داشت. وزن خشك براساس جدول r، در تيمارهاى دورهُ ششهفته سرمادهى وزن خشك كياهجهها از بقيه دورهها بالاتر بود و بالاترين وزن خشك كياهجه مربوط به همين دورةٌ تحت تيمار همراه با خراشدهى

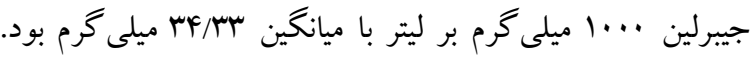
يايينترين وزن خشك گياهجه توسط تيمار همراه با خراشدهى آب مقطر در دورؤ سه هفته سرمادهى (به ميزان ه ميلى گرم) بدون اختلاف معنىدار با تيمارهاى بدون خر اشدهى و با خراشدهى تيواوره / / درصد در دوره صفر سرمادهى حاصل شد. در دوره ششهفته سرمادهى تيمار همراه با خراشدهى جيبرلين .10

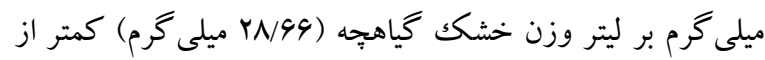
غلظت ...1 ميلى گرم بر ليتر همين تيمار در اين دوره بود، درحالى كه در دورههاى صفر و سههفته سرمادهى اين تيمار (به-

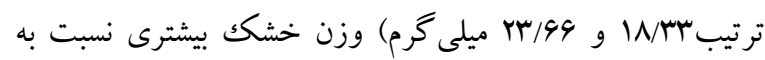


جدول r- مقايسه ميانكين برهم كنش سرمادهى، خراشدهى و تيمارهاى شيميايى شكست خواب براى برخى صفات جوانهزنى در بذر كنگر وحشى (حروف يكسان در هر

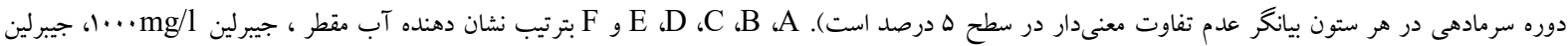

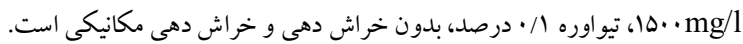

Table 2. Mean comparisons of interaction among stratification, scarification and seed dormancy breaking treatments for some germination traits in G. tournefortii. (Columns having a common letter in each stratification period are not significantly different from each other according to LSD 0.05). A, B, C, D, E and F represent Water, Gibberellin $1000 \mathrm{mg} / \mathrm{l}$, Gibberellin $1500 \mathrm{mg} / \mathrm{l}$, Thiourea $0.1 \%$, صithout scarification and mechanical scarifications, respectively.

\begin{tabular}{|c|c|c|c|c|c|}
\hline $\begin{array}{c}\text { دوره سرمادهى } \\
\text { Stratification period } \\
\text { (Week) هis }\end{array}$ & $\begin{array}{c}\text { خراش دهى مكانيكى } \\
\text { Mechanical scarification }\end{array}$ & $\begin{array}{c}\text { تيمارها } \\
\text { Treatments }\end{array}$ & $\begin{array}{c}\text { مول گياهجه } \\
\text { Seedling length } \\
\text { ميلىمتر (mm) }\end{array}$ & $\begin{array}{c}\text { وزن خشك كياهجه } \\
\text { Seedling dry weight } \\
\text { ميلى كرم(mg) }\end{array}$ & $\begin{array}{l}\text { شاخص بنه طولى كياهجه } \\
\text { Seedling vigor index }\end{array}$ \\
\hline صفر (0) & بدون خراش دهى(E) & آب مقطر (A) & $0^{\mathrm{e}}$ & $0^{\mathrm{f}}$ & $0^{\mathrm{f}}$ \\
\hline صفر (0) & بدون خراش دهى(E) & جيبرلين (B) & $0^{\mathrm{e}}$ & $0^{\mathrm{f}}$ & $0^{\mathrm{f}}$ \\
\hline صفر (0) & بدون خراش دهى(E) & جيبرين mg/10. (C) 10 ) & $0^{\mathrm{e}}$ & $0^{\mathrm{f}}$ & $0^{\mathrm{f}}$ \\
\hline صفر (0) & بدون خراش دهى(E) & تيواوره // درصد(D) & $46.33^{\mathrm{a}}$ & $6.66^{\mathrm{e}}$ & $19.4^{\mathrm{a}}$ \\
\hline صفر (0) & همر رخراش دهى(F) & آب مقطر (A) & $23^{\mathrm{b}}$ & $15^{\mathrm{c}}$ & $6.04^{\mathrm{b}}$ \\
\hline صفر (0) & همراه خراشدهى(F) & جييرلين (B) & $10^{\text {cd }}$ & $15.33^{b c}$ & $1.55^{\text {cde }}$ \\
\hline صفر (0) & همراه خراش دهى(F) & جييرلين (C) $10 \cdot$ mg/1 & $7.33^{\mathrm{d}}$ & $18.33^{\mathrm{a}}$ & 1.62 cde \\
\hline صفر (0) & همر اه خراش دهى(F) & تيواوره /·درصد(D) & $7.33^{\mathrm{d}}$ & $7^{\text {de }}$ & $2.11^{\text {cde }}$ \\
\hline سه(3) (3) & بدون خراش دهى(E) & آب مقطر (A) & $0^{\mathrm{d}}$ & $0^{\mathrm{e}}$ & $0^{\text {e }}$ \\
\hline (3) سه & بدون خراش دهى(E) & جيبرلين (B) 1 ...mg/1 & $0^{\mathrm{d}}$ & $0^{\mathrm{e}}$ & $0^{\mathrm{e}}$ \\
\hline (3) (3) & بدون خراش دهى(E) & 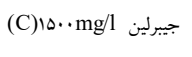 & $0^{\mathrm{d}}$ & $0^{\mathrm{e}}$ & $0^{\mathrm{e}}$ \\
\hline سه (3) & بدون خراش دهى(E) & تيواوره /·• درصد(D) & $0^{\mathrm{d}}$ & $0^{\text {e }}$ & $0^{\mathrm{e}}$ \\
\hline (3) سـ & همراه خراش دهى(F) & آب مقطر (A) & $7.33^{\mathrm{c}}$ & $5^{\mathrm{d}}$ & $0.49 \mathrm{de}$ \\
\hline (3) سـ & همر خراش دهى(F) & 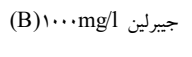 & $21^{\text {a }}$ & $17.33^{\mathrm{b}}$ & $5.6^{\mathrm{a}}$ \\
\hline (3) (3) & همراه خراش دهى(F) & جيرلين (C) $10 \cdot \cdot m g$ ج) & $17.33^{\mathrm{b}}$ & $23.66^{\mathrm{a}}$ & $1.86^{\mathrm{bc}}$ \\
\hline (3) سه (3) & همر اه خراش دهى(F) & تيواوره //• درصد(D) & $20.66^{\mathrm{a}}$ & $9^{\mathrm{c}}$ & $2.22 \mathrm{bc}$ \\
\hline (6) & بدون خراش دهى(E) & آب مقطر (A) & $0^{\mathrm{d}}$ & $0^{\mathrm{e}}$ & $0^{\mathrm{e}}$ \\
\hline (6) & بدون خراش دهى(E) & جيبرلين (B) 1 (.)mg & $0^{\mathrm{d}}$ & $0^{\mathrm{e}}$ & $0^{\mathrm{e}}$ \\
\hline (6) - 16) & بدون خراش دهى(E) & جيبرلين (C) $10 \cdot$. mg/1 & $0^{d}$ & $0^{\mathrm{e}}$ & $0^{\mathrm{e}}$ \\
\hline (6) & بدون خراش دهى(E) & تيواوره //:درصد(D) & $0^{\mathrm{d}}$ & $0^{\mathrm{e}}$ & $0^{\mathrm{e}}$ \\
\hline (6) & همراه خراش دهى(F) & آب مقطر (A) & $23^{b}$ & $18.66^{\mathrm{d}}$ & $1.53^{\mathrm{cd}}$ \\
\hline (6) & همر اه خراش دهى(F) & جيرلين (B) & $48.33^{\mathrm{a}}$ & $34.33^{\mathrm{a}}$ & $12.88^{\mathrm{a}}$ \\
\hline (6) & همراه خراش دهى(F) & جيرلين (C) $10 \cdot \cdot m g$ (ج) & $48^{\mathrm{a}}$ & $28.66^{b}$ & $5.28^{\mathrm{b}}$ \\
\hline (6) & همر اه خراش دهى(F) & تيواوره //• درصد(D) & $15^{\mathrm{c}}$ & $25.66^{\mathrm{c}}$ & $1.02^{\mathrm{cd}}$ \\
\hline
\end{tabular}

$$
\text { جدول r- ماتريس ضرايب همبستخى صفات اندازه گيرى شده بذر كنغر وحشى. }
$$

Table 3. Correlation coefficients matrix of measured traits in G. tournefortii.

\begin{tabular}{|c|c|c|c|c|c|c|c|}
\hline صفات اندازه گيرى شده & (1) & (2) & (3) & (4) & (5) & (6) & (7) \\
\hline درصد جوانهزنى(\%) Germination (1) & 1 & & & & & & \\
\hline سرعت جوانهزنى (2) Germination speed) & $0.528^{* *}$ & 1 & & & & & \\
\hline (3) Germination period average & $0.845^{* *}$ & $0.099^{\mathrm{ns}}$ & 1 & & & & \\
\hline (4) Seedling length طو كياهجه & $0.707 * *$ & $0.755^{* *}$ & $0.428^{*}$ & 1 & & & \\
\hline وزن خشك كياهجه (5) Seedling dry weight & $0.527^{* *}$ & $0.808^{* *}$ & $0.285^{\mathrm{ns}}$ & $0.764^{* *}$ & 1 & & \\
\hline بنيه طولى گياهجه (6) Seedling vigor) & $0.822 * *$ & $0.562^{* *}$ & $0.595^{* *}$ & $0.842^{* *}$ & $0.443^{*}$ & 1 & \\
\hline فعاليت آلفا آميلاز (7) $\alpha$-amylase activation & $-0.179^{\text {ns }}$ & $-0.206^{\mathrm{ns}}$ & $-0.150^{\text {ns }}$ & $-0.228^{\text {ns }}$ & $-0.361^{\mathrm{ns}}$ & $-0.077^{\mathrm{ns}}$ & 1 \\
\hline
\end{tabular}




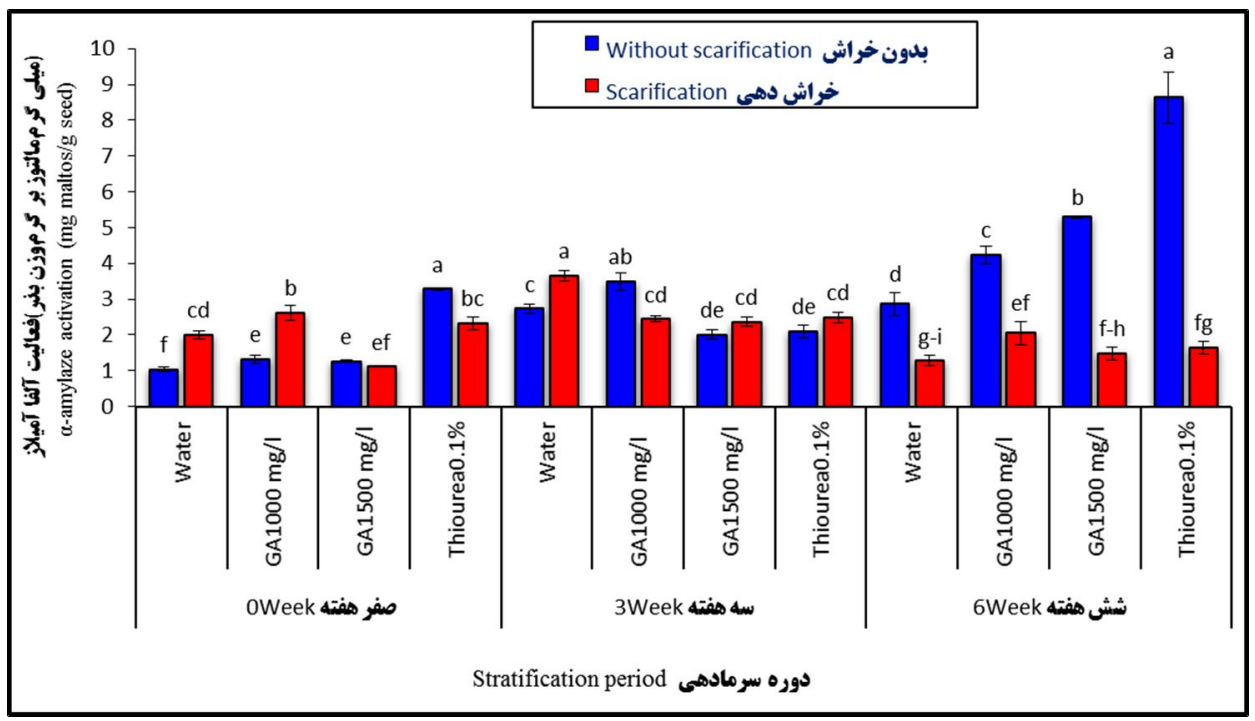

شكل ع - مقايسه ميانگين برهم كنش بين سرمادهى، خراشدهى و تيمارهاى شيميايى شكست خو اب براى فعاليت آلفا آميلاز در بذر كنگر وحشى (ستونهاى با حروف مشترك در هر

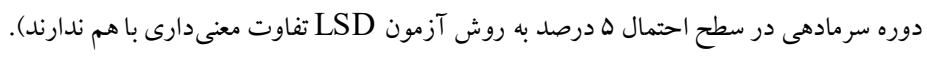

Fig. 4. Mean comparisons of interaction among stratification, scarification and dormancy breaking chemical treatments for $\alpha$ amylase activity of G.tournefortii. (Columns having a common letter in each stratification period are not significantly different from each other according to LSD 0.05).

Phartyal et al., 2003) (10..

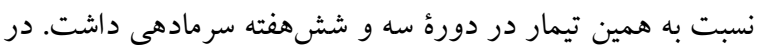

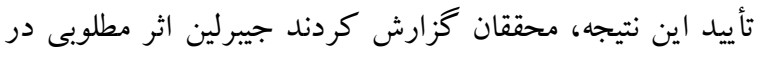
راهاندازى بسيارى از واكنشهاى آنزيمى مربوط به به جوانهزنى

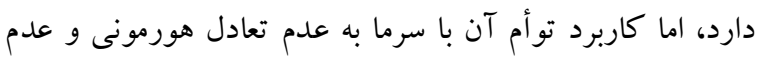

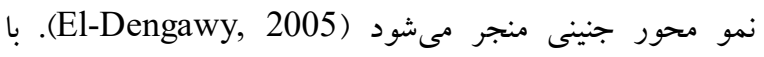
افزايش دورهٔ سرمادهى ميانگين درصد جوانه زنى كاهش نش نشان داد. Nabaee و همكاران (2013) هنگكام به كار گيرى تيمار

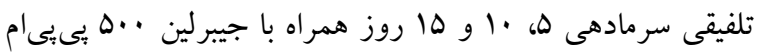
براى شكست خواب بذر خارمريم (Silybum marianum)

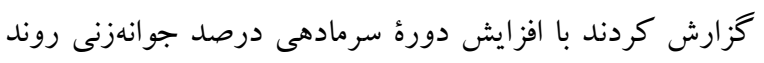

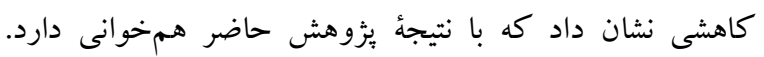

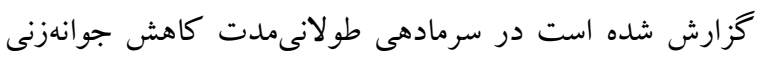

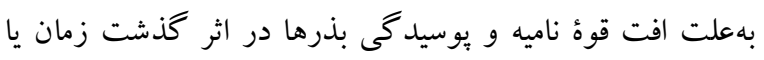

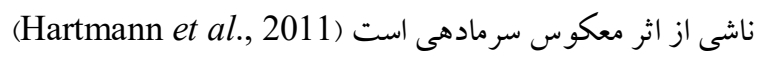

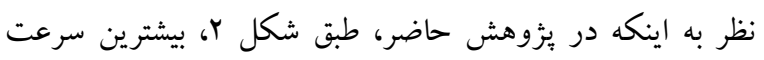

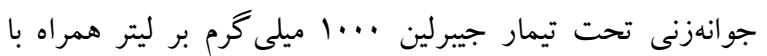

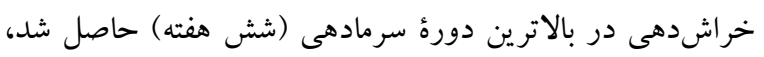

تحت تيمار بدون خراشدهى تيواوره / • درصد (N/9F ميلى گرم

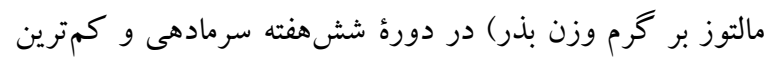

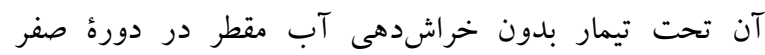

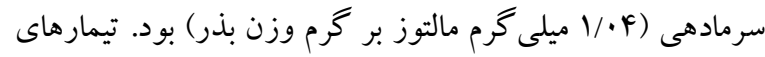

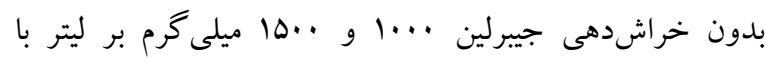

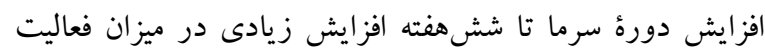

$$
\text { آنزيم آلفآميلاز نشان دادند. }
$$

نتايج آزمايش نشان داد با افزايش طول دورؤ سرمادهى، درصد

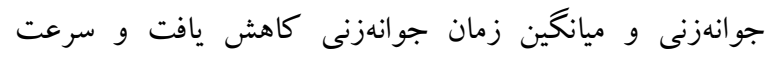
جوانهزنى، وزن خشكى، بنئ طولى و فعاليت آنزيم آلفآميلاز

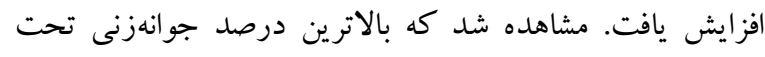

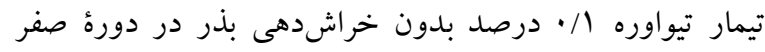

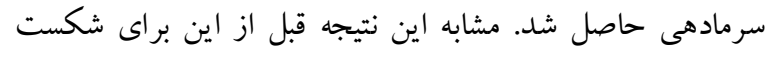

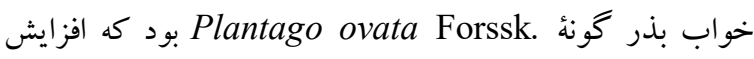

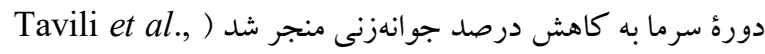

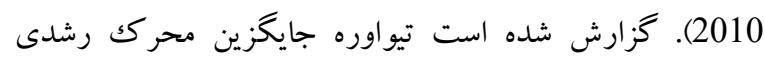
مىشود كه در حالت طبيعى در طى استراتيفيكاسيون ظاهر مىشود 
سرما، ميانخين زمان جوانهزنى تحت تيمار جيبرلين “. 10 ميلى گرم

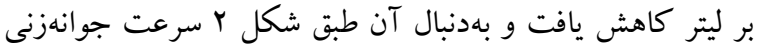
تحت اين تيمارها افزايش نشان داد. همسو با اين نتيجه، بررسى (2007) Abu-Qaoud براى تيمارهاى شكست خواب بذر سه

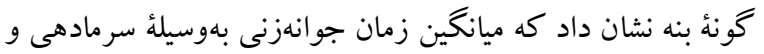

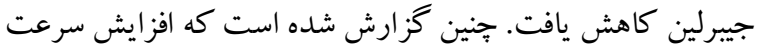
جوانهزنى بذرهاى تيمارشده با جيبرلين ممكن است ازطريق

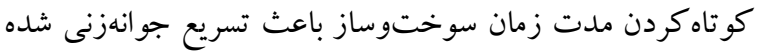
و بهدنبال آن به كاهش ميانگين زمان جوانهزنى منجر شود Baskin \& Baskin, 2004) از زمان جوانهزنى است و رابطةُ عكس با سرعت جوانهزنى دارد. هرجه اين شاخص كوجكت بر باشد نشاندهندة بالاتربودن سرعت جو انهزنى است (Tajbakhsh \& Gheasii, 2009). بهطور كلى، با افزايش دوره سرمادهى تا ششهفته ميانخين زمان جوانهزنى مربوط به اكثر تيمارها روند كاهشى و سرعت جو انهزنى روند افزايشى داشت. بالاترين طول كياهجه (جدول r) تحت تيمار همراه با خراش -

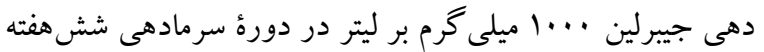
بود. كزارش شده است تيمار بذر كور (Capparis spinosa L.)

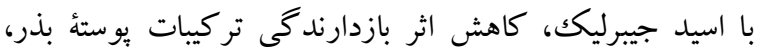

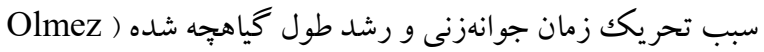
(et al., 2004 جيبرليك يكك هورمون عمده در تحريك جوانهزنى بذر است كه

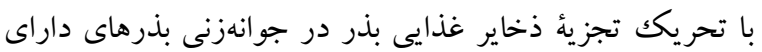

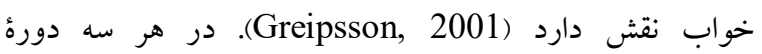

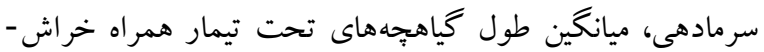

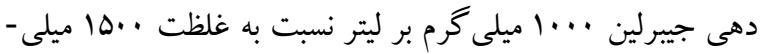

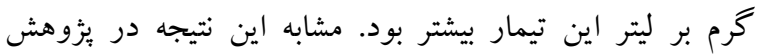
Rostamipour و همكاران (2015) تيمار خراشدهى جيبرلين

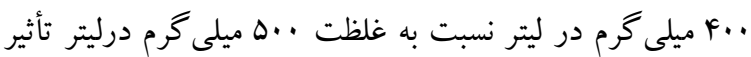
بيشتى در طول كياهجهها در هر سه اكوتيب مورد بررسى كون ايرانى داشت. دربارهُ وزن خشك كياهجِها (جدول r) تيمار

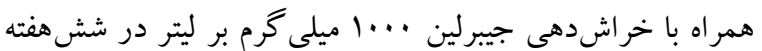

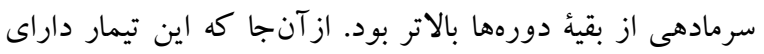

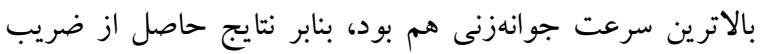

كزارش شده است سرما و اسيد جيبرليكك اغلب به تشكيل، آزادسازى يا فعالكردن آنزيمهاى هيدروليتيكى جهت تجزيه يروتئينها و نشاسته ذخيره شده در بذر جهت تغذيه جنين مىانجامد و بدينطريق سرعت جوانهزنى را افزايش مىدهد (Yamaguchi \& Kamiya, 2000). همبستخى مشاهدهده (جدول r) ميان سرعت جوانهزنى با درصد جوانهزنى (r=·/OrA**)

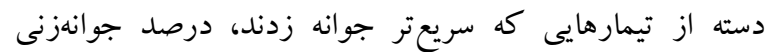
بيشترى هم داشتند. سرعت جوانهزنى بالاتر سبب خروج سريعتر

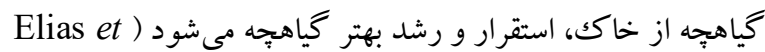
al., 2006 سرعت جوانهزنى تيمار همراه با خراشدهى جيبرلين

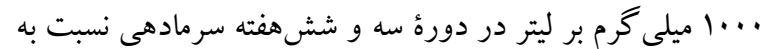

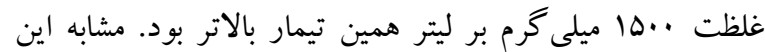
نتيجه، در بزؤهش Rostamipour و همكاران (2015) گزارش شد تيمار خراشدهى مكانيكى بههمراه جيبرلين با غلظت ع..

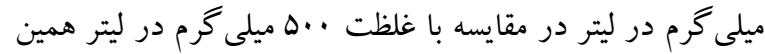
تيمار افزايش بيشترى در سرعت جوانهزنى بذر كون (Astragalus cyclophyllon Beck) يُزوهش حاضر با افزايش دورةٌ سرما سرعت جوانهزنى افزايش يافت و سرعت جوانهزنى تيمارهاى همراه با خراشدهى جيبرلين

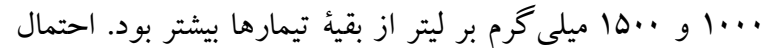
داده شده است، عامل سرما، علاوهبر تحريك سنتز جيبرلين درونزا، محر كهاى ديخرى را فعال كند كه سبب افزايش سرعت جوانهزنى مىشود و با كاهش تراز هورمونهاى بازدارنده و افزايش تراز هورمونهاى محرك سبب افزايش بيتانسيل جوانهزنى مىشود (Tipirdamaz \& Gomurgen, 2000). بالاترين ميانگين زمان جوانهزنى تحت تيمار بذرهاى بدون خراشدهى با هاب تيواوره // درصد در دوره صفر سرمادهى حاصل شد كه از مقاومت يوسته بذر در مقابل جوانهزنى حكايت دارد. همجنان كه در يُزوهش Mahmoodzadeh و همكاران (2005) دربارة شكست خواب بذر تاتوره (Datura stramonium L) صرفاً برش با اسكالِل باعث شكست خواب بذر شد. آنها در اين تحقيق

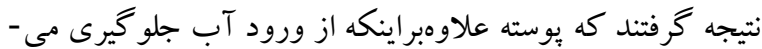

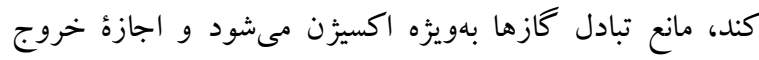

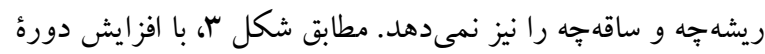


درصد جوانهزنى (r=•/AFr**) برطبق جدول س، بالابودن بنئ طولى گياهجه در برخى از تيمارها بديهى است و ناشى از بالابودن درصد جوانهزنى و طول گياهجه در بيزوهش حاضر، با وجود افزايش زياد فعاليت آنزيم آلفآميلاز در دوره ششهفته سرمادهى (شكل F) در بذرهاى تيمارشده با تيواوره / / درصد بدون خراشدهى، همانطور كه در بررسى درصد جوانهزنى تحت اين تيمار مشخص شد، جوانهزنى مشاهده نشد. بيش از اين، Munawar و همكاران (2015) Zزارش كردند بذرهاى Zaleya pentandra (L.) C.Jeffrey هيج ياسخى به غلظتهاى مختلف تيواوره و نيترات يتاسيم نشان ندادند؛ زيرا احتمالاً اين دو تيمار در شكافتن يوسته بذر ناموفق هستند و بذرها يس از خيساندن در اين تيمارها آماده جوانهزنى مىشوند، اما آنها فقط هنگامى جوانه مىزنند كه با سمباده شكافته شوند. تيمارهاى بدون خراشدهى جيبرلين ... كرم بر ليتر با افزايش دورهٔ سرما تا ششهفته افزايش قابل توجه در ميزان فعاليت آنزيم آلفآميلاز نشان دادند. گز ارش شده جيبرلينها سنتز آنزيمهاى هيدروليتكى را كه در زير لايهُ آلورون قرار دارند افزايش مىدهند، سُب آنزيمهاى سنتزشده به آندوسيرم انتقال مىيابند و سبب تجزئ مواد ذخيرهاى و تأمين انرزى لازم براى

جو انهنى مىشوند (Cirak et al., 2004).

نتيجه كيرى باتوجه به نتايج اين يزوهش، تيمار همراه با خراشدهى اسيد

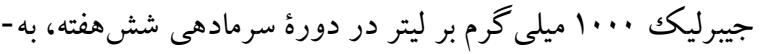
علت داشتن بالاترين سرعت جو انهزنى، طول كياهجه، وزن خشك گياهجه، همجنين كسب درصد جوانهزنى و بنية طولى كياهجه بالا و ميانگين زمان جوانهزنى نسبتاً يايين، مطلوب ترين تيمار براى شكست خواب بذر اين گياه محسوب مىشود و بهنظر مىرسد خواب بذر كنگر وحشى تركيبى ازخواب فيزيولوزيكى و فيزيكى

سياسگزارى

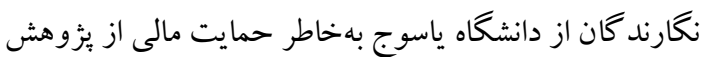
حاضر قدردانى مى كنند.
همبستكى (جدول ץ) مىتوان گفت كه ميان صفت وزن خشك كياهجه با درصد جوانهزنى (r=-/DYV**)، سرعت جوانهزنى

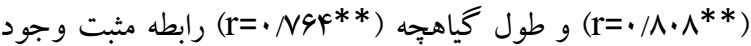
دارد. كفته شده است در تيمارهايى كه جوانهزنى سريعتر انجام مىشود، بخشى از آن بهمعناى شروع رشد و افزايش شاخصه ها در مقايسه با گياهجههايى است كه جوانهزنى راديرتر آغاز كردهاند و بخش ديخر احتمالاً به دليل تعديل هورمونى ايجادشده در اثر تيمار سرمادهى و نيز كاربرد خارجى اسيد جيبرليكك است كه باعث سنتز آنزيمهاى هيدروليز كننده مانند آلفآميلاز مىشود كه خود اين آنزيم سبب تجزيه نشاسته و درنتيجه انتقال مواد حاصل از تجزيه به جنين در حال رشد مىشود و از اين طريق طول كياهِه و وزن آن را افزايش مىدهد (Stout, 1998). در دورهُ شش هفته سرمادهى تيمار همراه با خراشدهى جيبرلين ."10 ميلى كرم بر ليتر وزن خشك گَاهجه كمتر از غلظت .... ميلى گرم بر ليتر همين تيمار بود. همسو با اين نتيجه، Rajabian و همكاران Ferula assa-) (2007) در يُزوهش شكست خواب بذر آنغوزه تحت تيمارهاى اسيد جيبرليك و سرمادهى گز ارش (foetida L. كردند غلظتهاى بيشتر از حد آستانهُ اسيد جيبرليكك بر جوانهزنى و بقية شاخصههاى بذر كياه اثر بازدارندگى دارد. براساس نتايج جدول Y، بيشترين شاخص بنية طولى گياهجه تحت تيمار بدون خراشدهى تيواوره // • درصد در دوره صفر سرمادهى حاصل شد. در بزؤهش شكست خواب بذر آويشن شيرازى ( Zataria (2015) Heshmati Asaadi توسط (moltiflore Boiss كزارش شد تيمار تيواورهُ ا مولار بدون سرمادهى باعث بهبود درصد جوانهزنى به ميزان سو درصد و شاخص بنيه طولى بذر به

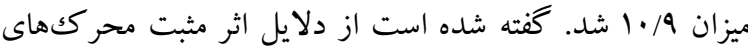
شيميايى مانند تيواوره بر جوانهزنى بذر احتمالاً به تعادلرسيدن نسبت هورمونى در بذر و كاهش بازدارندهاى رشد مانند اسيد آبسيزيك است. اين محر ككها باعث شكست خواب فيزيولوزيكى بذر مىشوند. در تيمار همر اه با خراشدهى جيبرلين .... ميلىكرم بر ليتر در دوره ششهفته سرمادهى شاخص بنئ طولى كياهجه نسبت به همين تيمار در دورهُ صفر و سهفته سرمادهى افزايش جشمخيرى داشت. با توجه به رابطة أو و ارتباط مستقيم بين صفت طول كياهجه، درصد جوانهزنى و بنيه طولى كياهجه و نيز رابطةٌ مستقيم و معنىدار صفت شاخص بنية طولى كياهجه با 


\section{REFERENCES}

Aghaei, R., Alvani-Nejad, S., Basiri, R. and Zolfaghari, R. 2012. The relationship between plant ecological groups and environmental factors (case study: Vezg habitat). Appl. Ecol. 1: 53-63.

Abu-Qaoud, H. 2007. Effect of scarification, gibberellic acid and stratification on seed germination of three Pistacia species. - An - Najah Univ. J. Res. 21: 1-11.

Aburajai, A., Darwish, R.M., Al-Kalil, S., Mahafzah, A. and Al-Abbadi, A. 2001. Screening of antibiotic resistant inhibitors from local plant materials against two different strains of Pseudomonas aeruginosa. - J. Ethnopharmacol. 76: 39-44.

Ahmad, M.Z. and Hussain, I. 2014. Effect of different treatments on the safe removal of seed dormancy in sunflower hybrid Hysun-33. - Persian Gulf Crop Protection (PGCP) 3: 1-5.

Apak, R., Guklu, K., Demirata, B., Ozyurek, M., Celik, S.E., Bektasoglu, B., Berker, K.I. and Ozyurt, D. 2007. Comparative evaluation of various total antioxidant capacity assays applied to phenolic compounds with the CUPRAC assay. - Molecules 12: 1496-1547.

Asaadi, A.M. and Heshmati, G.A. 2015. The effect of different treatments on breaking seeds dormancy and inducing germination of Thymus transcaucasicus Ronn. and Zataria moltiflora Boiss. - J. Plant Res. 28: 12-22.

Baskin, J.M. and Baskin, C.C. 2004. A classification system for seed dormancy. - Seed Sci. Res. 14: 1-16.

Bernfeld, P. 1995. Amylases alpha and beta. - Methods Enzymol. 1: 149-151.

Cirak, C., Ayan, A.K. and Kevseroglu, K. 2004. The effects of light and some presoaking on germination rate of St. John Worth (Hypericum perforatum L.) seeds. Pakistan J. Biol. Sci. 7: 182- 186.

Elias, S.G., Garary, A., Schweitzer, L. and Hanning, S. 2006. Seed quality testing of native specie. - Native Pl. J. 7: 15-19.

El-Dengawy, E.F. 2005. Promotion of seed germination and subsequent seedling growth of loaquat (Eriobotrya japonica) by moist-chilling $\mathrm{GA}_{3}$ applications. - Sci. Hort 105: 331-342.

Fang, S., Wang, J., Wei, Z. and Zhu, Z. 2006. Methods to break seed dormancy in Cyclocarya paliurus (Batal). Iljinskaja. - Sci. Hort. 110: 305-309 .

Greipsson, S. 2001. Effects of stratification and $\mathrm{GA}_{3}$ on seed germination of a sand stabilizing grass Leymus arenarius used in reclamation. - Seed Sci. Technol. (SST) 29: 1-10.

Halabi, S., Battah, A.A., Aburjai, T. and Hudaib, M. 2005. Phytochemical and antiplatelet investigation of Gundelia tournifortii. - Pharm. Biol. 43: 496-500.

Hartmann, H.T., Kester, D.E., Davies, F.T. and Geneve, R. L. 2011. Plant propagation principles and practices. Prentic hall, NewJersey, Eight edition. 880 pp.

Hashemedezfuli, S.A. and Aghaalikhani, M. 1998. Seed dormancy and germination. - University of Shahid Chamran Press, 246 pp.

ISTA. 1996. International rules for seed testing. - Seed Sci. Technol. 13: 299-513.
ISTA. 2010. International rules for seed testing. International Seed Testing Association. Zurich. 139 pp.

ISTA. 2011. International Seed Testing Association. ISTA Working Sheets on Tetrazolium Testing, vol: 1, $1^{\text {st }}$ edition 2003, supplement 201, Basserdorf, Switzerland.

Jamshidzadeh, A., Fereidooni, F., Salehi, Z. and Niknahad, H. 2005. Hepatoprotective activity of Gundelia tournifortii. - J. Ethnopharmacol. 101: 233-237.

Kondo, T. 1993. Promotion of hard seed germination in Lotus corniculatus var japonica for use in amenity grasslands. - Seed Sci. Technol. 21: 611-619.

Mahmoodzadeh, A., Nojvan, M. and Bagheri, Z. 2005. Effects of different treatments on breaking of dormancy and seed germination of Datura stramonium L. - J. Plant Res. 18: 341-349.

Manjkhola, S., Dhar, U. and Rawal, R.S. 2003. Treatments to improve seed germination of Arnebia benthamii: an endangered medicinal herb of high altitude Himalaya. Seed Sci. Technol. (SST) 31: 571-577.

Munawar, S., Naeem, M., Ali, H.H., Jamil, M., Iqbal, M., Nazir, M.Q., Balal, R.M. and Safdar, M.E. 2015. Seed dormancy breaking treatments for African purslane (Zaleya pentandra). - Pl. Danin. 33: 623-629.

Nabaee, M., Roshandel, P. and Mohammad Khani, A. 2013. The effects of plant growth regulators on breaking seed dormancy in Silybum marianum L. - J. Cell Tissue 4: 45-54.

Nasiri, M., Madah Arefi, H. and Isvand, H.R. 2004. Evaluation of viability changes and dormancy breaking in the seed of some species in Natural Resources Gene Bank. - Iranian Journal of Rangelands and Forests Plant Breeding and Genetic Research 12: 163-182.

Olmez, Z., Yahyaglu, Z. and Omer, A. 2004. Effect of $\mathrm{H}_{2} \mathrm{SO}_{4}, \mathrm{GA}_{3}$ and $\mathrm{KNO}_{3}$ treatment on germination of Caper seeds. - Pakistan J. Biol. Sci. (PJBS) 7: 879-882.

Phartyal, S.S., Thapliyal, R.C., Nayal, J.S. and Joshi, G. 2003. Seed dormancy in Himalayan maple (Acer caesium) I: Effect of stratification and phytohormones. Seed Sci. Technol. 31: 1-11.

Por-Esmaeel, M. and Sharifi, M. 2003. Study effect stratification and cytokinin several on seeds dormancy breaking Bunium persicum. - Iran. J. Med. Arom. Plants 19: 183-195.

Rajabian, T., Saboora, A., Hassani, B. and Fallah Hosseini, H. 2007. Effects of $\mathrm{GA}_{3}$ and chilling on seed germination of Ferula assafoetida. - Iran. J. Med. Arom. Plants 23: 391-404.

Rostamipour, A., Moradi, A., Isvand, H. and Nasiri, M. 2015. Investigation of seed dormancy type and its breaking methods in 3 ecotype Iranian Astragale (Astragalus cyclophyllus) pasture plant. - Iran. J. Sci. Technol. Seed 4: 51-56.

Sarmadniya, G. 1996. Seed technology. - Mashhad University Press. 228pp.

Stout, D. 1998. Rapid and synchronous germination of Cicer milkvetch seed following diurnal temperature priming. - Crop Sci. 181: 263-266.

Tajbakhsh, M. 1996. Seed (cognitive-certification and control). - Tabriz Ahrar Publications. 179 pp.

Tajbakhsh, M. and Gheasii, N. 2009. Seed ecology. Urmia, Jihad Daneshgahee 134 pp. 
Tavili, A., Pouzesh, H., Farajolahi, A., Zare, S. and Chahooki, M.A. 2010. The effect of different treatments on improving seed germination characteristics in medicinal species of Descurainia sophia and Plantago ovata. - Afr. J. Biotechnol. 39: 6588-6593.

Tipirdamaz, R. and Gomurgen, N. 2000. The effects of temperature and gibberellic acid on germination of Eranthis hyemalis L. Salisb Seeds. - Turk. J. Bot. 24: 143-145.

Yamaguchi, S. and Kamiya, Y. 2000. Gibberellin biosynthesis: its regulation by endogenous and environmental signals. - Plant Cell Physiol. 41: 251-257.

How to cite this article:

Vaisi, Gh., Mohtadi, A. and Moradi, A. 2018. The effect of different treatments on seed germination and dormancy breaking in seeds of Gundelia tournefortii - Nova Biologica Rep. 5:26-37.

ويسى، غ.، مهتدى، ا. و مرادى، ع. Vوسا. تاثير تيمارهاى مختلف بر جوانه-

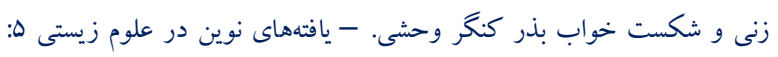
rY-rV 